\title{
Sharing the Earth: A biocentric account of ecological justice
}

\author{
Wienhues, Anna
}

\begin{abstract}
Although ethical and justice arguments operate in two distinct levels - justice being a more specific concept - they can easily be conflated. A robust justification of ecological justice (justice to nature) requires starting at the roots of justice, rather than merely giving, for example, an argument for why certain non-human beings have moral standing of some kind. Thus, I propose that a theory of ecological justice can benefit from a four-step justification for the inclusion of non-human beings into the community of justice, starting with Hume's circumstances of justice. I will further argue that the resulting theory of ecological justice should be biocentric - meaning that all living beings should be included into the community of justice, as they constitute a 'community of fate'.
\end{abstract}

DOI: https://doi.org/10.1007/s10806-017-9672-9

Posted at the Zurich Open Repository and Archive, University of Zurich ZORA URL: https://doi.org/10.5167/uzh-169664

Journal Article

Published Version

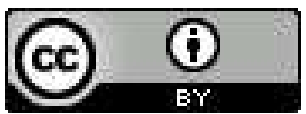

The following work is licensed under a Creative Commons: Attribution 4.0 International (CC BY 4.0) License.

Originally published at:

Wienhues, Anna (2017). Sharing the Earth: A biocentric account of ecological justice. Journal of Agricultural and Environmental Ethics, 30(3):367-385.

DOI: https://doi.org/10.1007/s10806-017-9672-9 


\title{
Sharing the Earth: A Biocentric Account of Ecological Justice
}

\author{
Anna Wienhues ${ }^{1}$ (D)
}

Accepted: 20 June 2017/Published online: 30 June 2017

(C) The Author(s) 2017. This article is an open access publication

\begin{abstract}
Although ethical and justice arguments operate in two distinct levelsjustice being a more specific concept - they can easily be conflated. A robust justification of ecological justice (justice to nature) requires starting at the roots of justice, rather than merely giving, for example, an argument for why certain nonhuman beings have moral standing of some kind. Thus, I propose that a theory of ecological justice can benefit from a four-step justification for the inclusion of nonhuman beings into the community of justice, starting with Hume's circumstances of justice. I will further argue that the resulting theory of ecological justice should be biocentric-meaning that all living beings should be included into the community of justice, as they constitute a 'community of fate'.
\end{abstract}

Keywords Biocentrism - Circumstances of justice - Ecological justice · Flourishing $\cdot$ Environmental ethics

\section{Introduction}

How can 'we' live well together on one planet with a finite amount of resources crucial for life? While a sixth mass extinction caused by humans is taking its course, it seems that 'we' cannot merely refer to humanity anymore. However, political theorists have struggled for millennia to provide a satisfying answer to how life should be organised within a single society and fairly recently they have turned to considering human relations on a global scale. When acknowledging that humanity is not alone, the problem of how to live well together on one planet then gains even

Anna Wienhues

anna.wienhues@manchester.ac.uk

1 Sustainable Consumption Institute, University of Manchester, 188 Waterloo Place, Oxford Road, Manchester M13 9PL, UK 
more magnitude. During the last two decades a new body of literature has sprung up that tries to tackle this problem (directly or indirectly) via the concept of ecological justice (see Baxter 2005; Nussbaum 2006; Schlosberg 2007; Garner 2013). Coined by Low and Gleeson (1998), ecological justice is the idea of doing justice to nature and forms the counterpart to environmental justice which is concerned with justice between humans with regard to nature.

However, ethical arguments and arguments about justice are not the same and this distinction remains also true outside the human realm. For example, a convincing argument that keeping farm animals in small cages is wrong because it causes them suffering does not automatically lead to the claim that these animals are entitled to a certain amount of space and food in order for their situation to be (distributively) just. In the ecological justice literature these two domains have often been conflated-e.g. by putting more emphasis on 'moral considerability' than on more specific circumstances of justice (as seen in Baxter 2005) or-as has been noted by Robert Garner (2013) — by inferring a justice discourse from a discourse on rights (as seen in Regan 1984). In order to make a strong case for ecological justice and thereby tackling the question of how to life together on a finite planet it seems necessary to keep a clear distinction between the realm of ethics and the more particular realm of justice. ${ }^{1}$ As argued for by Garner (2013), in practice the high status of justice can be a helpful tool to support nonhuman interests as arguments that do not rely on justice can more easily be put aside as less stringent requirements such as duties of charity. For example, cosmopolitans have used this move from duties of charity to duties of justice to strengthen the claims of strangers living far away. Hence, the idea of ecological justice is not merely interesting for environmental philosophers but also for environmental activists.

Therefore, grounded justification for ecological justice-meaning a conception that is clearly embedded in justice-requires starting at the roots of justice and not merely an argument for why certain non-human beings have moral standing of some kind. In this paper, I propose that this justification requires a four step process as a method for including non-human beings into the community of justice and I argue that all living beings should be included. This conclusion is reached by building on ethical biocentrism and bringing this perspective further into the realm of politics via the concept of justice.

In the first step I go back to David Hume's 'circumstances of justice' as a foundation for analysing whether the human-nonhuman relationship actually falls within these circumstances which constitute the 'origin story' of justice in the sense that they generate conditions to which justice can provide answers. Hume probably would have argued that the human-nonhuman relationship does not fall within these circumstances. The point, however, is that justice applies as a 'solution' to the problems embodied by the circumstances of justice (Hope 2010). This means that justice is a contextual concept that aims to solve some problems arising from actual existence and hence it stands in comparison to moral laws which are supposed to

\footnotetext{
1 This distinction between ethics and justice also indicates that a theory of ecological justice is part of and not a substitution for a more general theory of environmental ethics. Hence, not all ethical issues that apply to the human-nonhuman relationship can be resolved by a theory of ecological justice.
} 
have a more universal applicability. Furthermore, depending on what we define as the circumstances of justice they take on the function of weeding out all inappropriate theories that cannot make sense of these circumstances (Hope 2010). From a pluralist perspective this means that there is not one set of universally valid circumstances for all kinds of justice, but that depending on the scope of our inquiry different problems/circumstances need to be taken into account.

The second step is then to outline what constitutes justice. This is difficult in so far as justice is a contested concept. However, one's definition of justice has strong implications for what or who is included into the community of justice and what principles of justice we think apply within this community. At the third step, which is where the focus of the ecological justice discussion has been laying so far, we can inquire into who or what might be included into a community of justice based on what we think justice is and what circumstances we need to take into account. Then in the final step we can start to consider what principles of justice apply to this particular justice community.

In what follows I discuss each of the first three steps in turn: the circumstances of justice, the nature of justice and the community of justice all in reference to ecological justice in order to provide a more grounded reasoning for including nonhumans into the community of justice than provided by some theories of ecological justice so far. Based on this, the conclusion will be that all living beings should be included into this community of ecological justice which I call a 'community of fate' because it constitutes a non-consensual sharing of destiny.

Because of space constraints I will neither be able to discuss what principles of justice (step four) might apply to this justice community nor all the implications that arise from human-nonhuman conflicts. However, three important preliminary remarks should be mentioned before beginning with the main discussion. Firstly, even though distributive justice is not the only aspect of justice the focus of my discussion lies on this particular kind of ecological justice. This means that other aspects of justice such as recognition might also be applicable in the context of human-nonhuman relations (see Schlosberg 2007). Nevertheless, distributive justice appears most relevant in the context of a finite planet because 'ecological space' is becoming more and more scarce and thereby threatening the wellbeing and survival of many different living beings.

Secondly, I regard 'ecological space' to be the appropriate object of distribution in this context. This is because, in theory, it is a concept that includes everything needed to sustain life because it can be understood as the aggregation of all 'lifesupporting natural resource-based goods and services' (Vanderheiden 2009: 257). Further consideration will need to be given to the issues that most environmental 'services' are generated by living beings and that many living beings are also considered to be environmental 'goods' themselves (e.g. trees). ${ }^{2}$

Thirdly, there exist to some degree irresolvable conflicts between humans and nonhumans as there will always be the need for humans to harm or kill other beings

\footnotetext{
${ }^{2}$ For a more detailed description of the ecological space concept see Hayward (2015) or Peeters et al. (2015). More thought will need to be given to developing a non-anthropocentric conceptualization of ecological space.
} 
(even if it is merely picking vegetables in a field) and, conversely, humans can also be considered to be environmental 'goods' themselves that are 'used' by some other living beings (e.g. some kinds of bacteria). Depending on what view one holds on the relationship between ideal and non-ideal theory in political thought, it could either be argued that it is impossible to construct an ideal theory of ecological justice (as a fully just 'end-state') but only to enquire whether certain situations are more or less just if one considers these conflicts to be fundamentally problematic. ${ }^{3}$ Or one can claim that ecological justice can still be framed within the domain of ideal theory by providing different weights to all claims which would lead to an overall just outcome. While keeping these differences and that they do not exhaust all understandings of ideal/non-ideal theory in mind, I will return to this issue in the next section which indicates that these 'deep' conflicts imply that ecological justice is limited to comparing more or less just situations as the needs of all living beings can never be meet simultaneously. ${ }^{4}$

\section{Step 1: Circumstances of Justice}

As argued above, an inquiry about justice should ideally start with a consideration of David Hume's 'circumstances of justice' (CoJ) — as termed by John Rawls (1971). If justice is supposed to be the solution, then the CoJ embody the problems that cannot be ignored (or idealized away). In other words, justice is supposed to be the answer to exactly the problems that are represented by the CoJ (Hope 2010). When looking at a society a prime example of such a problem or 'circumstance' would be the limited access to necessary and luxury goods for its members.

In the context of justice to nature a question is whether any theory of ecological justice can actually get started in the sense that nonhumans are included in the CoJ. If they are deemed to be outside such circumstances then the whole project of ecological justice seems futile. On a first glance, this appears to be a difficult undertaking. As Elizabeth Cripps points out, the CoJ as they are traditionally understood do not really match up with how 'natural' societies function (2010).

Fortunately, the idea of the CoJ and the concept of ecological justice seem compatible which results from considering the three relevant questions in this context (which are discussed in the following subsections). Firstly, how exclusionary are traditionally conceived Humean circumstances of justice towards nonhumans really? This is an important question for some theorists of social justice that might be reluctant to move away from or expand the Humean/Rawlsian set of accepted CoJ. However, how the CoJ have been understood traditionally was a function of the issue in question which was how to live well together in a society (e.g. via cooperation). The problem here, on the other hand, is a different one from social justice. The starting question for ecological justice is how to live well together on one finite planet and, then, this sets the problem background for

\footnotetext{
3 Schlosberg takes the latter perspective by understanding ecological justice as a 'problem-solving theory' (2014).

${ }^{4}$ For an overview of the different understandings of ideal and non-ideal theory see Valentini (2012).
} 
enquiring into what the appropriate $\mathrm{CoJ}$ as well as the complementary understanding of the nature of justice are in this context. As mentioned above, justice is a contextual concept that aims to solve some problems arising from actual existence and from a pluralist perspective this means that there is not one set of universally valid circumstances for all kinds of justice. Deconstructing the purpose of the CoJ makes this fluidity clearer. The CoJ have a dual but interrelated meaning. On the one side, they flesh out the problem context by adding 'realistic' factors that explain the need for the establishment of rules. On the other side, the $\mathrm{CoJ}$ function also as parameters that allow justice to be a solution within their limits. From this dual understanding follow two questions that need answering. Firstly, what $\mathrm{CoJ}$ in terms of problems that need to be accounted for apply to the human-nonhuman relationship? If justice is context specific then this is the least controversial question to answer as it allows the $\mathrm{CoJ}$ to differ in the ecological justice and social justice cases as they need to take into account (potentially) different problem factors. The last question then regards how $\mathrm{CoJ}$ function as parameters limiting the applicability of ecological justice. This issue seems more problematic for establishing ecological justice because the human-nonhuman case might not be compatible with moderate (i.e. limited) scarcity-meaning enough for everybody's needs but not everyone's wants-which is a key circumstance of justice within the theories of Hume and Rawls.

\section{The traditional CoJ}

Simon Hope's (2010) discussion of Hume provides a useful starting point for the first issue. Hume claimed that 'limited scarcity' and 'confined generosity' were necessary CoJ. This means in situations outside of these circumstances (which have upper and lower boundaries) justice would not apply. For example, if there would be an endless amount of certain goods available it would not make much sense to consider how to justly distribute these goods. According to Hope, Hume clearly excluded animals from these CoJ because on the one side his conception of justice was strongly linked to owning possessions. This is, however, part of step two of the justification process (i.e. what justice is about) and hence not relevant at this point because it can be detached from the idea of $\mathrm{CoJ}$ (as has been also argued by Salter 2012). Hence, up to here it seems that non-humans might as well be 'within' the CoJ because Hume distinguishes between the origins of justice-i.e. the circumstances of justice-and who, or what, justice actually applies to. It is when discussing the latter that Hume excludes nonhumans from the community of justice because these simply cannot own property.

On the other side, however, Hume also adds a less well known condition or circumstance to his list-rough 'equality of powers' - which is more or less met 'by the simple fact of human interdependence' (Hope 2010: 137) and hence this excludes animals from the CoJ by failing to fulfil this equal powers criterion which it seems can only be fulfilled by humans. ${ }^{5}$ This is consistent with Salter's (2012)

\footnotetext{
5 This refers to Hume's discussion in An Enquiry Concerning the Principles of Morals and A Treatise of Human Nature.
} 
reading of Hume's 'equality of powers' passage. Contrary to many critics (such as Barry 1989), Salter claims that the requirement of equality of powers does not force Hume to exclude weak or disabled people from the domain of justice. Rather, it is a requirement that applies between species instead of between individual human beings because - according to Hume- 'we develop a self-interested disposition to abstain from the possessions of other human beings, including those human beings who have no capacity to harm us' (2012: 3). Hence, more simply, it appears that Hume's position is to make 'being human' the inclusion/exclusion criterion to what kind of beings justice can apply by framing it as a 'motivational' circumstance of 'equal powers' of some sort which refers again to his conception of justice that focuses on property. Therefore, by excluding the content of justice that is focused on property out of Hume's considerations of the CoJ, these appear to be also applicable to nonhumans. The only issue that remains is that it is not nonhumans per se but the human-nonhuman relationship that does not seem to fall within the traditional CoJ. More specifically, the circumstance of limited (or moderate) scarcity is problematic, which is where Cripps critique of the $\mathrm{CoJ}$ in the context of the nonhuman seems to aim at (2010). I will turn to this point below.

\section{The problem-context}

Others, most prominently Rawls, have picked up Hume's idea and modified it slightly. According to Rawls, for example, CoJ are 'conditions under which human cooperation is both possible and necessary’ (1971: 109). By understanding the CoJ in this manner (very similarly to how Rawls understands justice itself), he has excluded non-human beings from being subjects of justice right at the first step. He then carries on and lists some 'objective' CoJ (moderate scarcity and human similarity and vulnerability) and some 'subjective' CoJ (mutual disinterestedness and limited knowledge) (Freeman 2014). Similarly, Hope adds his own considerations to Hume's list. Similar to Rawls, he adds human vulnerability to each other's actions and ethical variety (2010). Considering that $\mathrm{CoJ}$ are contextual, I want to propose in the following a tentative list of circumstances that would apply to the human-nonhuman relationship and thereby to start to answer the question about which circumstances in terms of contextual problems need to be taken into account in the case of the human-nonhuman relationship. This list is not necessarily complete, but the following three points appear to be issues that theories of ecological justice cannot ignore.

Firstly, as proposed by Hume and Rawls 'scarcity' needs to be part of a list of CoJ. This is as true in the context of ecological justice as for any considerations of distributive justice but it is especially relevant in the context of a finite planet which provides the main 'problem context' for ecological justice. However, the applicability of justice should not just be confined to merely limited or moderate scarcity because, arguably, (1) the language of justice is applicable to all situations below extreme abundance and short of full societal collapse and (2) in the case of ecological justice moderate scarcity is a circumstance which is unachievable because of inevitable conflicts between humans and nonhumans that do not allow for the (theoretical) satisfaction of everyone's and everything's needs at the same 
time. I will return to this second point below. Regarding the first point it seems fairly clear that abundance of all kinds of goods undermines the need for distributive justice. Hence, this 'circumstance' gives the applicability of justice an upper bound-somewhere short of a 'land of milk and honey'. However, regarding its lower boundary I disagree with the point that it must entail that there is enough to fulfil everyone's needs. The applicability of justice must stretch into a territory were needs clash, otherwise we might be today or in the near future already outside the $\mathrm{CoJ}$ in regard to environmental goods and services even in the context of social justice. $^{6}$ As has been argued by Hubin (1979), in the end the distribution in circumstances of moderate/limited scarcity is merely 'simpler' than in more scarce circumstances, but that does not mean that distributive justice in circumstances of severe scarcity is inconceivable. As Hubin has rightly pointed out, cases of 'severe scarcity' are not that rare-even in wealthy societies-as, for example, the distribution of donor organs to people with kidney failure shows. Therefore, scarcity is a $\mathrm{CoJ}$ in the context of ecological justice but it stretches into an area of conflicting needs where traditional theorists of justice have been reluctant to enter.

Secondly, also some sort of confined generosity (Hume) or mutual disinterestedness (Rawls) should be kept on the list. The main point here is that there are many (potential) conflicts of interests between different parties-some of which justice can help to resolve such as sharing limited resources. If people would be generally virtuous individuals keen to be generous, there would arguably not be much left for justice to resolve. The same seems true in the context of human conduct towards other species where no reciprocity applies.

Thirdly, Hope's addition of 'vulnerability' to the actions of others should be included as well (Hope 2010: 14). This point is important because it stresses the fact that each individual life happens in the context of many other living beings and each being's actions can causally impact the livelihood of the others. ${ }^{7}$ Contrary to Hope, who only considers justice between humans, it appears obvious that not only humans are vulnerable to the actions of others, but all other life forms as well, such as polar bears suffering from anthropogenic climate change. This point has been also similarly been made by Brian Baxter who claims more generally that circumstances of justice also extend to other 'morally considerable' beings because also their 'welfare interests' can be affected (2005).

\section{Never-ending conflicts}

The understanding of the $\mathrm{CoJ}$ as parameters that limit the applicability of justice as a solution is challenging in the context of the human-nonhuman relationship because the human-nonhuman case is not compatible with moderate scarcity (where all needs can potentially be met) which is a key circumstance of justice within the theories of Hume and Rawls. Including nonhumans in the relevant group of beings

\footnotetext{
6 This is a problem in so far as one might want to turn to justice for answers in particularly these more difficult cases.

7 Similarly, O'Neill has made the point that in light of human vulnerability it is the function of justice to protect from injury (1996).
} 
means that meeting all needs is never-even not theoretically-possible. This is because some beings use other beings as necessary 'resources' for their survival and flourishing. For example, for some bears salmon is an important part of their nutrition. By meeting this need, however, the bear cuts the life of the salmon short. ${ }^{8}$ Hence, it is not just that justice should not be limited to (only) moderate scarcity, rather in the case of ecological justice moderate scarcity seems impossible to achieve. For some theories of ecological justice this is a major area of concern as I will discuss in the next section. However, even when focusing only on the humannonhuman relationship and thereby excluding all intra-nature relationships from the scope of justice deep seated conflicts arise. For example, the needs of a salmonella bacterium are not compatible with the needs of its human host. Hence, also deepseated conflicts between humans and nonhumans remain.

Because of this problem ecological justice has to take on a different form than traditional conceptions of (social) justice and the following are its four main implications. Firstly, as I will elaborate in the next section, ecological justice can only work with a negative or 'thin' version of justice because otherwise it would run into many difficulties by trying to solve deep-seated conflicts. Secondly, on an individual level this means that ecological justice is imperfect in the sense that the needs of all individual beings can never be satisfied simultaneously. This then seems to indicate that a theory of ecological justice might only be a 'problem-solving' theory of justice where one can only distinguish between more or less unjust scenarios (see Schlosberg 2014). As justice will always be imperfect in humannonhuman context, this then explains how a theory of ecological justice can allow for the 'defence' of one's own flourishing in situations of conflict (e.g. by taking antibiotics). When and how such actions are permissible will need to be further spelled out in step four (which is not part of this paper) but it is interesting that even a theory of ecological justice that takes a moral egalitarian perspective can justify harmful actions towards nonhumans based on the imperfect nature of ecological justice.

Thirdly, in the grand scheme of things, ecological and social justice are to some extent complementary (Cripps 2010). This then eases many of the conflicts that persist on an individual level when considering on a more societal level how to live and what policies to adopt. For example, policies that aim at intergenerational justice between humans usually also benefit current and future nonhuman beings. In the end, most living beings have an 'interest' in humans pursuing sustainable practices (in the strong sustainability sense at least).

Fourthly, the residual conflicts that hinder ecological justice to still not be able to achieve circumstances of moderate scarcity might be circumvented if ecological justice is limited to the relationship between humans and 'wild' nonhumans only (e.g. excluding farm animals and crops), and if conflicts where humans embody the role of the prey (e.g. of the salmonella bacterium) are set aside as well. This last point is especially relevant for considering what principles of justice (step four)

\footnotetext{
8 There are, of course, many examples of plants, bacteria and animals using each other as 'resources' but without needing to harm their 'resource' or by even living in an symbiotic relationship.
} 
follow from ecological justice, but also this issue will have to be fleshed out further in a different paper.

\section{Step 2: Conception of justice}

In step one I discussed some fairly general problems or circumstances that justice needs to be able to resolve or answer. However, this discussion still does not tell us what kind of a solution justice embodies and because justice is a contested concept its content is difficult to pin down. Rawls' A Theory of Justice (1971) is probably the most famous articulation of what justice is about. Rawls bases his theory on what he calls a 'political conception of justice' which forms the basis of cooperation for 'reasonable' citizen within a liberal society (Wenar 2012). He thereby looks at justice from the angle of wanting to decide on the most appropriate system of cooperation for a society which embodies a 'cooperative venture for mutual advantage' (Rawls 1971: 4) with justice applying to the 'basic structure' of that society. Hence, one of the main points of his theory is to determine a just 'division of advantages from social cooperation' (Rawls 1971: 6) within a fairly closed off society.

Arguably, however, considerations of justice are applicable to more than just this very specific situation envisioned by Rawls. For example, there exist extensive bodies of literature claiming that justice also applies on a global level (e.g. Caney 2005; Risse 2012) and between generations (e.g. Grosseries and Meyer 2009). Hence, it is possible to conceive justice as applicable to many different scenarios. What they all have in common, however, appears to be a connection between everyone (or everything) in the in-group where justice applies and an out-group where it does not. For Rawls, for example, a delineated liberal society constitutes the in-group (or community of justice) which is held together by cooperation; or for some cosmopolitans, the common humanity of all humans triggers considerations of justice in the global sphere and excludes all nonhumans from these particular considerations. Therefore, what triggers considerations of justice and therefore determines the specific nature of justice is interlinked with the nature of the in-group that generates justice considerations. This makes it to some degree impossible to differentiate between what justice is about and the in-group in consideration (see step three), because it is only in reference to an actual group of beings that thinking about justice makes any sense.

In step three I will argue that all living beings on Earth form together a justice community understood as 'a community of fate' and it is towards this particular community that a conception of justice applies in the form discussed here. This means that I do not directly argue against, for example, a Rawlsian definition of justice. I merely want to claim that what justice is about depends on the problem context to which it is applied and that in my much 'broader' scenario (that includes all living beings on Earth) justice should be conceived as being about enabling flourishing.

Hence, under these conditions, justice's 'goal' or 'solution' is, more specifically, that all species can flourish after their own kind as the puzzle it refers to is 
'coexistence' and not 'cooperation'. There is nothing in the circumstances of justice-as defined above-that excludes non-humans from the domain of justice, nor is there anything in this specific definition of justice that discounts nonhuman beings, as all living beings have the innate ability to flourish. Hence, my understanding of justice is here very similar to how capability theorists (like Fulfer 2013; Nussbaum 2006) or ecological feminists (like Cuomo 1998) have defined it. ${ }^{9}$

The concept of flourishing is usually traced back to Aristotle's eudaimonia, which gets translated as happiness or flourishing. It constitutes the final or most complete good for humans (Crisp in Aristotle 2000), which is 'an activity of the rational soul, conducted in accordance with virtue or excellence' (Shields 2015). However, more simply and without reference to virtue ethics, one could say that every being that has a life also has a good (Von Wright 1963) and to live in accordance with this good appears intuitively to be some kind of 'full' way of living which constitutes flourishing. Hence, flourishing embodies the idea of the 'good life'. In the following step I will argue that all living beings are included in the community of justice and hence being alive is the cut-off point and not sentience for inclusion into the realm of justice. Based on this emphasis on life, the focus is here on flourishing because all living beings have the ability to live a 'good' life and thus flourish. ${ }^{10}$

In the domain of environmental ethics, several scholars have supported some version of the claim that every being that is alive also has a good. For example, Rolston (2012) and Taylor (1986) have argued about life in general and Attfield (1981) has argued regarding trees in particular that these beings have a good of their own, even though they disagree on whether the concept of 'interests' is applicable to nonconscious beings such as plants. In Rolstons words, '[e]very organism has a good-of-its-kind' (2012: 97, italics in original). Similarly, also Taylor states that ' $[\mathrm{t}]$ he biocentric outlook on nature... includes a certain way of perceiving and understanding each individual organism. Each is seen to be a teleological (goaloriented) centre of life, pursuing its own good in its own unique way' (Taylor 1986: 44-45). In the end, the idea of a 'good' held by living beings is one way of showing that it makes sense to speak of the wellbeing of a living entity in contrast to any inanimate object which has none. It is precisely this close connection between life and wellbeing that provides the concept of life with the moral force it is often intuitively ascribed (Von Wright 1963). ${ }^{11}$ Furthermore, based on this link it then can be distinguished between whether an organism is merely living or living well and this allows us to think of it in terms of its flourishing as a way of describing the 'good life' of each individual organism. Therefore, a conception of justice that takes

\footnotetext{
${ }^{9}$ E.g. Fulfer claims that 'relationships and flourishing' are 'what we take to be the crucial aspect of justice' (2013: 27) and Nussbaum claims that the capabilities approach 'wants to see each thing flourish as the sort of thing it is' (2006: 349). Similarly, Cuomo states that '[a] defining feature of ecological feminist thought is its commitment to the flourishing, or well-being, of individuals, species, and communities' (1998: 62).

${ }^{10}$ The category of all living beings includes a wide range of different organisms ranging from bacteria to whales.

${ }^{11}$ An alternative view is Sentientism (e.g. Singer 1989) which claims that it is the suffering of sentient beings which really matters instead. See Goodpaster (1978) for a counterargument.
} 
into account all living beings because they are morally considerable on the grounds of being entities that strive for their own wellbeing aims to 'solve' the puzzle of coexistence of all these individual beings.

From this point of view, life is then a concept that describes the 'goaldirectedness' of an entity to strive for its own wellbeing. It might seem that a fair amount hinges on what particular definition of life is used to distinguish between what entities are covered by justice, but the several definitions that have been brought forward by biologists and environmental ethicists do not necessarily exclude each other. ${ }^{12}$ On the contrary, there appears to be significant overlap that allows for convergence on most issues. Therefore, an account that sees living beings striving for their own good is compatible with more biologically focused views such as Humberto Maturana and Francisco Varela's autopoiesis theory which claims that living organisms are 'self-maintaining and self-producing systems' (See DeplazesZemp and Biller-Andorno 2012: 959) or a view that understands living beings as the bearers of genes. Even though there are marginal cases (e.g. viruses), the distinction between living beings and inanimate objects is usually clear. The point is that living beings are more than just machines. Even though machines can have a goal (or rather a function) the relevant difference is that machines do not have wellbeing that is intrinsic to themselves but their goal can only be instrumental to the wellbeing of some other living entity. As put by Nicholas Agar, there is a distinction between 'other-directed' and 'self-directed' goals and only the latter actually refer to the entity's own good (1997).

What (objective) good a being has depends on its nature which makes the matter a bit more complicated in the human case where a distinction can be made between a more basic or animal nature and a cultural nature and hence a range of different 'substantive theories of the good' which humans can hold. Even though questions about human nature bring us onto difficult terrain, they are unavoidable as their resolution helps us to understand what we, as humans, need (see Biro 2016) and what then ultimately is considered human wellbeing or flourishing. ${ }^{13}$ The concept of need and what constitutes human flourishing, in turn, are then highly relevant when one wants to consider how to distribute certain goods - such as ecological spaceas they influences the strength of claims to certain amounts of ecological space which, in turn, have implications regarding what claims of distributive justice humans might have towards the Earth's ecological space.

In the nonhuman case, pinning down what constitutes the good of each being is not an easy task either, but by bracketing out the issue of culture and individual actualization the focus lies with nonhuman beings on the kind of being it is-i.e. its species. Hence it is easier to tentatively generalize what the good of a being is in the nonhuman case and thereby provide an 'objective' definition of what constitutes flourishing for the members of a certain species (Fulfer 2013). For example, with regards to (vascular) plants, Kallhoff (2014) has listed three conditions for plant

\footnotetext{
${ }^{12}$ For an overview of different conceptions of life see Deplazes-Zemp and Biller-Andorno (2012), Palmer (2016) and Agar (1997).

13 Following from this, questions also arise regarding what needs refer to which aspect of human nature (i.e. animal or cultural). While arguably the former is more stable, the justifications of cultural needs are far more contested in the context of sustainability.
} 
flourishing which constitute together a description of the 'good life' for plants. These are the ability to react 'to external stress without endangering the overall performance which sustains its life' (2014: 687); the ability to accomplish its lifecycle; and succeeding 'in expressing the typical characteristics both of a plant which has specific life-form and of more specific organisms, generally fitting its species description' (2014: 687). In practice, it might then be necessary to construct similar lists of criteria for flourishing for most kinds of living beings. In any case, a being flourishes when it lives 'fully', by living in accordance with its own good; what kind of good it has depends on what kind of being it is.

Some people might think that such an understanding of justice is inconsistent with a liberal approach to justice such as justice as impartiality (e.g. see Barry 1995). However, even though the approach defended here differs in many respects from many liberal justice theories, justice in the sense of enabling flourishing does not constitute a substantive theory of the good-each being keeps jurisdiction over what constitutes its own good. Justice understood in this manner merely restricts the range of acceptable substantive theories of the good that are compatible with the flourishing of others. This still holds when one not just considers the flourishing of humans but also regard the rest of nature. ${ }^{14}$

However, in order to make this understanding of justice-especially in the context of ecological justice - a bit less controversial and more in line with the restrictions outlined in the discussion of the circumstances of justice above it seems useful to think of it being understandable in two ways. A positive interpretation would require the (active) supporting of flourishing. This is the more demanding version which would demand from agents of justice the assisting of the flourishing of other beings, even if their non-flourishing status is fully independent of the agent's actions. Following this interpretation, agents of justice (humans) would have a duty of justice to provide the conditions needed for subjects of justice (nonhumans) to flourish. A negative interpretation would require (merely) not inhibiting flourishing. This interpretation is more in line with definitions of justice that see it as a kind of negative duty not to harm (e.g. O'Neill 2010). On this understanding justice merely demands of humans not to negatively interfere with the lives of nonhumans-e.g. by destroying their habitat. The positive interpretation (supporting flourishing by enabling/creating the possibility of flourishing) is very demanding and following the discussion above such a positive interpretation would run in into the problem that not all needs can be satisfied at the same time when nonhumans are included in the scope of justice. This is illustrated by the problems the capabilities approach runs into by attempting to support flourishing via capabilities (as seen for example in Nussbaum 2006). This can be illustrated by the dilemma of the opposing interests of prey and predator as, for example, the flourishing of a hungry lion is not compatible with the flourishing of a nearby antelope. The negative interpretation avoids this problem, because from this perspective it is not a requirement of justice to help certain species to flourish if their 'non flourishing status' is not due to any human actions. For example, under this

\footnotetext{
14 This potential extension to other beings stands in contrast to Barry's own position that considers questions of ecological justice to fall into the category of a substantive theory of the good (Baxter 2000).
} 
approach there is no need to protect the prey from the predator-as long as humans did not introduce the predator in the first place (e.g. by introducing new species into an ecosystem). The capabilities approach runs into such a problem because its focus lies on enabling capabilities, and hence it faces the dilemma that one cannot necessarily enable the capabilities of all individual beings (or species) simultaneously (Cripps 2010). ${ }^{15}$

Hence, I merely want to argue for the more modest claim that only the negative interpretation of justice as flourishing applies to the non-human living world. This means that in the case of non-human nature the focus is on refraining from injustice rather than 'providing' justice in the positive sense. Hence, even if some might refuse to apply a more extensive account of justice to the non-human world, they might accept that this rather 'thin' sense of justice applies. ${ }^{16}$

In this account justice remains an intrinsically human concept and hence only originates with humans as the 'distributor' and the rest of nature merely being recipients, because justice can only apply to human conduct as it is a concept that helps only humans to structure the world. Humans as the distributor can either distribute what they already have or take something away. In the ecological space sense it appears that humans as the distributors can only 'take away' because the ability to distribute appears connected to some conception of ownership which is something that humans do not have over the entirety of the available ecological space. ${ }^{17}$ The negative interpretation of justice as flourishing fits into this context by understanding the taking away of ecological space as the inhibition of flourishing if too much is taken away.

Understanding justice in the sense of flourishing points to one relevant (lower) threshold. Living beings have a set of 'flourishing needs'. ${ }^{18}$ For justice it is relevant for a being to get over this flourishing threshold (as well as the more basic survival threshold) and from the perspective of the negative interpretation this amounts to the requirement not to inhibit flourishing. Even though it is possible to diminish the flourishing of a being but that being keeps on flourishing (because it is possible to flourish to a greater or lesser degree), bringing a being's state below the flourishing threshold is what matters primarily for justice. In this sense, it matters for justice that a being can at least flourish after its own kind and not that it achieves the

\footnotetext{
15 Following up from the discussion in the previous section, by understanding ecological justice in this way and by limiting it to living beings I try to avoid some of the deep conflicts intrinsic to some capability approach versions of ecological justice as proposed by Martha Nussbaum (2006) who runs into the preypredator problem and Schlosberg $(2007,2014)$ who generates an even more conflictual picture by bringing ecosystems into the scope of justice. However, by keeping a commitment to flourishing I believe that my proposal here is meant in a similar spirit.

16 Furthermore, from a pluralist perspective the resulting duties of justice that follow from this account are merely 'simple' duties of justice as opposed to 'all things considered' duties of justice that take all different spheres of justice into account. Therefore, from this perspective duties of ecological justice can potentially still be overruled by other duties of justice which makes it less problematic to claim, for example, that a single bacterium can have claims of justice.

17 This position does require a justification of why humans do not 'own' the Earth which, for example, stands in contrast to Risse's 'ownership of the Earth' thesis (2012).

18 This links back to a paper by Elizabeth Anscombe where she claims regarding an organisms that " $\mathrm{t}] \mathrm{o}$ say that it needs that environment is not to say, e.g. that you want it to have that environment, but that it won't flourish unless it has it' (Anscombe 1958: 7).
} 
maximum level of flourishing theoretically possible. Because of this distinction, I frame the justice requirement as 'not inhibiting flourishing' instead of 'not harming flourishing'. It seems problematic to define harm in the sense of a threshold because it does not capture everything that is intuitively regarded as harm (see Hoozer 2008). For example, reducing somebody's level of welfare is also considered to be a harm, but as long as it does not drag them below the flourishing threshold this does not necessarily have to concern us in the context of justice.

To recapitulate, a being can flourish-more or less-after its own kind and there is a 'flourishing threshold' that needs to be achieved. In the scenario of a community of all living beings, justice is about not inhibiting flourishing whereby flourishing constitutes some kind of full life.

\section{Step 3: The community of justice: sharing the earth}

Having laid out the foundations of ecological justice in the first two sections I would like to now turn to the step on which inquiries of ecological justice have usually focused-who or what is included into the ecological community of justice. My main argument for including all living (and not merely sentient) beings is as follows, whereby points one to four are merely a reiteration of the argument so far.

1. Being $X$ is alive.

2. All beings that are alive have a good.

3. All beings that have a good can flourish.

4. Therefore, $\mathrm{X}$ is able to flourish.

5. Being $\mathrm{Y}$ is an Earthly being. This means the Earth is its only viable basis of existence.

6. If $\mathrm{Y}$ is also $\mathrm{X}$, then it is able to flourish and it needs the Earth's environmental goods and services to do so.

7. There are many beings of the type XY.

8. Therefore, all beings of type XY need to share the Earth.

The sharing of the Earth embodies a relationship of justice which is not generated by a semi-voluntary or hypothetical social contract but rather by the coincidence of simultaneous evolution. It does not matter whether one wants to describe the Earth as a lifeboat, a spaceship or the like-the basic intuition remains the same: that we are a 'community of fate'. This is an active, interdependent relationship which is implicit in it being a sharing relationship as opposed to mere co-existence, even though the condition of co-existence is a necessary prerequisite for this relationship. It is a community of fate because it rests on sharing the most fundamental basis of everyone's and everything's being without giving individual beings a choice in the matter. It is precisely because it is a non-consensual sharing of destiny that makes it a community of fate. This means that in order to live all beings XY have to share something-the Earth—which is inextricably linked to themselves. ${ }^{19}$

\footnotetext{
${ }^{19}$ It is important to note here that 'sharing' does not imply any form of ownership in this context. Hence, justice is not borne out of an ownership relationship here. On the contrary, the argument here is that
} 
For most people this might not be a sufficient reason to believe that justice is supposed to apply in this context, because, yes, there might indeed be a relationship that is observable here but it still does not lead to considerations of justice. They might just want to concede that it is necessary to at least take non-human interests into consideration. However, one needs to make the above-mentioned distinction between distributing ecological space to nonhumans and taking needed ecological space away from nonhumans which is illustrated by the following example.

1. Humans do not own the Earth. The Earth is not owned but commonly inhabited by all species.

2. Hence, by leaving enough ecological space for other species to live and flourish we, as humans, do not redistribute from the owners of these recourses to some benefiters that claim that they need them.

3. However, by taking more away than would leave nonhumans with enough ecological space we 'harm' them by impeding their functioning and flourishing.

4. It might be difficult to define justice and many would disagree with its above definition, but (3) seems intuitively to be an injustice. Hence, regarding nature we can maybe settle on a 'thin' sense of justice which only requires us not to inhibit flourishing.

Furthermore, this is a biocentric account which puts life-or being alive-at the centre of attention. Even if one denies that being alive in a common biosphere is a sufficient condition for generating claims of justice one might still have to grant it some importance in the domain of ethics, where life is due at least some moral respect (e.g. see Rolston 2012). In the sphere of environmental ethics (without extending their arguments to the realm of justice) several authors have claimed that 'life' is an appropriate criterion for inclusion into the realm of ethics, such as Kenneth Goodpaster who claimed that '[n]othing short of the condition of being alive seems to me to be a plausible and nonarbitrary criterion' for being morally considerable (1978: 310; italics in original). Nevertheless, I want to make here a more specific case - a biocentric account of justice. Following the argument set out above, all living beings have needs which refer to their ability to live and to flourish. It is these needs held by living entities that pursue their own good that are in competition for the Earth's goods and services. And it is because these needs refer to the same object of need-ecological space-and this object of need is spatially clearly circumscribed and without alternative-the Earth-that some kind of sharing 'arrangement' needs to be found between all needy beings. Obviously such an arrangement cannot be actively negotiated by involving all beings that have a stake in its outcome, but from a human perspective the requirement is to take into account that all human usage of ecological space has an impact on the ability of other beings to live and flourish. The nonhuman usage of ecological space influences in turn what there is for humans to take (while assuming a finite planet). Therefore, my main point is that all living beings on Earth-beings that live and not

Footnote 19 continued

justice can apply without any form of 'common ownership' all beings hold towards the Earth. Rather, the originally unowned status of the Earth frees the way for ecological justice. 
merely exist; beings that have a good and can flourish-do not merely coexist on Earth by living independent lives but are bound together by a sharing relationshipa relationship that determines their fate.

The discussion so far has been focused on individual organisms and thereby maintaining the liberal focus on the individual. But why are ecosystems not included in the community of justice as, for example, proposed by Schlosberg (2007)? According to Katy Fulfer, an ecosystem is 'a natural environmental system composed of abiotic and (sentient and nonsentient) biotic entities that interact, support, and depend on each other's existence' (2013: 32). She argues further that ecosystems can be regarded as 'organic wholes' which have value that is not 'necessarily reducible' to the overall value of its parts (2013: 32). This points to the not uncommon claim that ecosystems are more than just the value of their parts. Mathews (1991), for example, has claimed that not just organisms but also ecosystems (and the cosmos as a whole) are self-realizing in the relevant sense and hence 'living' beings in their own right. Similarly, also Schlosberg argues that '[s]ystems are living entities with their own integrity' (2007: 148).

However, there are three main reasons-besides the conflicts of needs discussed above-for why ecosystems are not included here in the community of justice. Firstly, it seems a bit more difficult to define what ecosystems are than put forward by Fulfer. As put by Cripps, 'individual ecosystems are not fixed or finite' (2010: 13). This is a problem insofar as one would want to consider them within the framework of distributive justice where 'goods' are 'distributed' to (spatially and to some degree temporally) discrete entities. Secondly, are ecosystems really as selfrealizing as individual living beings are? It seems that they are rather more or less stable states of equilibria formed out of all the interactions of biotic and abiotic entities, climatic conditions and other events and relationships. Furthermore, if ecosystems have similar properties to living beings, what would be the 'good' of an ecosystem? Some might argue that it would be its stability or integrity, but this appears to paint a very static picture of what ecosystems are. Rather, ecosystems appear to some degree dynamic and changing over time. The point is that change itself is not inherently bad, even though it can be catastrophic at times. Moreover, as claimed above, life is a concept that describes the 'goal-directedness' of an entity to strive for its own wellbeing. Even if one would grant the claim that ecosystems can have a good, for ecosystems to be alive in this way they would also need to exhibit some degree of goal-directedness towards that good. Similar to species (see Powell 2011), ecosystems appear to lack features that would imply a certain level of (nonaccidental) goal-directedness such as internal coordination. ${ }^{20}$ Thirdly, it might be true that ecosystems have individual value that is more than the sum of their individual components but that is not necessarily relevant for justice. To reiterate, justice, as defined here, is about the flourishing of living beings that have a good and ecosystems are just not 'alive' in the relevant sense. Of course, the health or stability of ecosystems is instrumentally important to all living beings in them. Hence claiming that all life should be able to flourish, protected by justice, also provides a derivative protection from considerable anthropocentric influence on ecosystems.

${ }^{20}$ See Cahen (1988) for a more detailed argument against the moral considerability of ecosystems. 
This last point also applies to populations. Most living organisms have to differing degrees the need to be immersed within a population in order to flourish. Hence populations are of instrumental value for the well-being of individual organisms. This does not mean, again, that a population does not have some independent value which matters (e.g. which can provide additional reasons for protecting endangered species)—but it does not matter necessarily within the narrow context of justice. Of course, how important it is for a being to be immersed in a healthy population depends on the kind of being it is. For example, Baxter (2005) has claimed that in the case of the 'merely living' beings (e.g. plants or some animals such as corals), it is not the individual but its respective population that is the bearer of claims in the context of justice because these beings lack individuality and sentience. Even though I would argue that members of non-individualized and non-sentient species can also flourish and that therefore populations per se are not the bearers of any claims, many beings are highly dependent on being part of a healthy population. Hence in practice in many cases it appears necessary to think in terms of populations instead of individuals in order to enable the flourishing of individuals.

\section{Conclusion}

In this paper I have tried to show that it is useful for approaches to ecological justice to follow a four-step justification process in order to consistently argue for the inclusion of nonhuman beings in the community of justice and hence the separation of ecological justice from the more general discussion of environmental ethics. Following this structure I have defended my proposal for grounding ecological justice. In the first step I devised my own list of 'circumstances of justice', comprised of scarcity, the confined generosity of humans and vulnerability to others, which apply to ecological justice.

In the second step I have argued that justice is about enabling flourishing in this context and that a negative interpretation of this understanding of justice as "not inhibiting flourishing' can be applied to human behaviour towards nonhuman life. Then, in the third step I have argued for all living organisms being part of the community of ecological justice which in turn constitutes a community of fate in which all members have to share the Earth.

I have bracketed many issues such as — on a more abstract level—what justice principles might follow from this approach and what it demands regarding our conduct towards and relationships with the rest of nature in practice. For example, are we required to subscribe to an agenda to 'set aside' half of the Earth for other species as proposed by the naturalist Edward O. Wilson (2016)? If yes, then how can the tension between this goal and other justice considerations such as environmental justice be dealt with in the context of a growing human population? Complications aside, extending the scope of justice to all nonhuman life appears theoretically possible and practically useful for everyone committed to the wellbeing and continued existence of nonhumans as it brings nonhumans closer into the realm of politics. Indeed, as global justice scholars have demonstrated, 
using the language of justice seems to be a more powerful for those seeking to defend the vulnerable than the language of charity.

Acknowledgements I thank my supervisors Sherilyn MacGregor and John O'Neill. Thanks are also owed to Christian Schemmel and several collegues in the field for their helpful comments on earlier versions of this paper. Previous versions of this paper were presented at the 2016 Brave New World conference at the University of Manchester and the 2016 ECPR graduate conference at the University of Tartu. This paper was written during my doctoral research conducted at the University of Manchester and funded by the Sustainable Consumption Institute.

Open Access This article is distributed under the terms of the Creative Commons Attribution 4.0 International License (http://creativecommons.org/licenses/by/4.0/), which permits unrestricted use, distribution, and reproduction in any medium, provided you give appropriate credit to the original author(s) and the source, provide a link to the Creative Commons license, and indicate if changes were made.

\section{References}

Agar, N. (1997). Biocentrism and the concept of life. Ethics, 108(1), 147-168.

Anscombe, G. E. M. (1958). Modern moral philosophy. Philosophy, 33(124), 1-19.

Aristotle. (2000). Nicomachean Ethics (R. Crisp, Trans.). Cambridge: Cambridge University Press.

Attfield, R. (1981). The good of trees + philosophy of intrinsic value and ecology. Journal of Value Inquiry, 15(1), 35-54.

Barry, B. (1989). A treatise on social justice, vol 1: Theories of justice. Berkeley: University of California Press.

Barry, B. (1995). Justice as impartiality. Oxford: Oxford University Press.

Baxter, B. (2000). Ecological justice and justice as impartiality. Environmental Politics, 9(3), $43-64$.

Baxter, B. (2005). A theory of ecological justice. London: Taylor and Francis.

Biro, A. (2016). Human nature, non-human nature, and needs: Environmental political theory and critical theory. In T. Gabrielson, C. Hall, J. M. Meyer, \& D. Schlosberg (Eds.), The Oxford handbook of environmental political theory (pp. 89-102). Oxford: Oxford University Press.

Cahen, H. (1988). Against the moral considerability of ecosystems. Environmental Ethics, 10(3), $195-216$.

Caney, S. (2005). Justice beyond borders. Oxford: Oxford University Press.

Cripps, E. (2010). Saving the polar bear, saving the world: Can the capabilities approach do justice to humans, animals and ecosystems? Res Publica, 16(1), 1-22.

Cuomo, C. J. (1998). Feminism and ecological communities: An ethic of flourishing. London: Routledge.

Deplazes-Zemp, A., \& Biller-Andorno, N. (2012). Explaining life. EMBO Reports, 13(11), 959-963.

Freeman, S. (2014). Original position. In E. N. Zalta (Ed.), The stanford encyclopedia of philosophy (Fall 2014 ed.). Online.

Fulfer, K. (2013). The capabilities approach to justice and the flourishing of nonsentient life. Ethics and the Environment, 18(1), 19-38.

Garner, R. (2013). A theory of justice for animals: Animal rights in a nonideal world. Oxford: Oxford University Press.

Goodpaster, K. E. (1978). On being morally considerable. Journal of Philosophy, 75(6), 308-325.

Grosseries, A., \& Meyer, L. H. (Eds.). (2009). Intergenerational justice. Oxford: Oxford University Press. Hayward, T. (2015). Ecological space: The concept and its ethical significance. In S. M. Gardiner, \& A. Thompson (Eds.), The Oxford handbook of environmental ethics (Oxford Handbooks Online ed.): Oxford University Press.

Hoozer, B. (2008). Fairness, Needs and Desert. In M. Kramer (Ed.), The legacy of HLA hart: Legal, political, and moral philosophy. Oxford: Oxford University Press.

Hope, S. (2010). The circumstances of justice. Hume Studies, 36(2), 125-148.

Hubin, C. D. (1979). The scope of justice. Philosophy and Public Affairs, 9(1), 3-24. 
Kallhoff, A. (2014). Plants in ethics: Why flourishing deserves moral respect. Environmental Values, 23, 685-700.

Low, N., \& Gleeson, B. (1998). Justice, society and nature. London: Routledge.

Mathews, F. (1991). The ecological self. Oxon: Routledge.

Nussbaum, M. C. (2006). Frontiers of justice: Disability, nationality, species membership. Cambridge, Mass.: Belknap Press.

O'Neill, O. (1996). Towards justice and virtue: A constructive account of practical reasoning. Cambridge: Cambridge University Press.

O’Neill, J. (2010). The overshadowing of need. In F. Rauschmayer, I. Omann, \& J. Fruehmann (Eds.), Sustainable development: Capabilities, needs, and well-being. London: Routledge.

Palmer, C. (2016). Living individuals: Biocentrism in environmental ethics. In S. M. Gardiner \& A. Thompson (Eds.), The Oxford handbook of environmental ethics (Oxford handbooks (Online ed.). Oxford: Oxford University Press.

Peeters, W., Dirix, J., \& Sterckx, S. (2015). Towards an integration of the ecological space paradigm and the capabilities approach. Journal of Agricultural and Environmental Ethics, 28(3), 479-496.

Powell, R. (2011). On the nature of species and the moral significance of their extinction. In T. L. Beauchamp \& R. G. Frey (Eds.), The Oxford handbook of animal ethics (Oxford Handbooks (Online ed.). Oxford: Oxford University Press.

Rawls, J. (1971). A theory of justice (Revised ed.). Cambridge, Mass.: Belknap Press.

Regan, T. (1984). The case for animal rights. London: Routledge.

Risse, M. (2012). On global justice. Princeton: Princeton University Press.

Rolston, H., III. (2012). A new environmental ethics: The new millennium for life on earth. New York: Routledge.

Salter, J. (2012). Hume and mutual advantage. Politics, Philosophy and Economics, 11, 1-20.

Schlosberg, D. (2007). Defining environmental justice: Theories, movements, and nature. Oxford: Oxford University Press.

Schlosberg, D. (2014). Ecological justice for the anthropocene. In M. Wissenburg \& D. Schlosberg (Eds.), Political animals and animal politics (pp. 75-89). Houndmills: Palgrave Macmillan.

Shields, C. (2015). Aristotle. In E. N. Zalta (Ed.), The stanford encyclopaedia of philosophy (Fall 2015 ed.). Online.

Singer, P. (1989). All Animals are Equal. In T. Regan \& P. Singer (Eds.), Animal rights and human obligations (pp. 148-162). New Jersey: Prentice Hall.

Taylor, P. (1986). Respect for nature: A theory of environmental ethics (25th Anniversary ed.). Princeton: Princeton University Press.

Valentini, L. (2012). Ideal vs. non-ideal theory: A conceptual map. Philosophy Compass, 7(9), 654-664. Vanderheiden, S. (2009). Allocating ecological space. Journal of Social Philosophy, 40(2), 257-275.

Von Wright, G. H. (1963). The varieties of goodness. London: Thoemmes Press.

Wenar, L. (2012). John Rawls. In E. N. Zalta (Ed.), The stanford encyclopaedia of philosophy (Winter 2013 Edition). Online.

Wilson, E. O. (2016). Half-earth: Our Planet's fight for life. New York: Livelight Publishing Corporation. 